\title{
COMPETENCY OF CLASS TEACHERS IN THE IMPLEMENTATION OF GUIDELINES DEMANDS IN EXTRAORDINARY ELEMENTARY SCHOOLS
}

\author{
Nani Triani', Uman Suherman ${ }^{2}$, Juntika Nurihsan ${ }^{3}$ \\ ${ }^{1}$ West Java Province Education Office \\ ${ }^{2}$ Indonesian Education University \\ ${ }^{3}$ Indonesian Education University \\ 1nanitriani68@gmail.com, ${ }^{2}$ umans@upi.edu, ${ }^{3}$ juntikanurihsan@upi.edu
}

\begin{abstract}
This research departs from the fact that learning with nuances of guidance in extraordinary elementary schools has not been done much so that the purpose of this study is to find out data about these matters. This study uses a quantitative approach with descriptive methods with 34 teachers as respondents. Areas that become indicators are mastery of identification and assessment of students, the ability of teaching theories \& principles of educational learning, and the development of learning tools with instructional learning principles. The results showed that in the mastery of identification and assessment, most of the students were in the less competent category, a few were competent, and the rest were less skilled. The ability to master learning theory and educational learning principles shows that most of them are in the competent category and the rest are in the weak and incompetent category, while the ability to develop learning tools following nuanced learning guidance is mostly in the category of resting competent very competent, incompetent and less competent. Based on the data obtained in the research results, it shows that the competence of elementary school class teachers is extraordinary in carrying out guided learning and shows excellent competence so that it still requires development assistance using various techniques, methods, strategies, and appropriate approaches.
\end{abstract}

Keywords: Competence of Classroom Teachers in Extraordinary Primary Schools, Guided Learning.

\begin{abstract}
Abstrak
Penelitian ini beranjak dari fakta bahwa pembelajaran bernuansa bimbingan di Sekolah Dasar Luar Biasa (SDLB) masih belum banyak dilakukan sehingga tujuan penelitian ini adalah untuk menemukan data hal tersebut. Penelitian ini menggunakan pendekatan kuantiaitif dengan metode deskriptif dengan jumlah reponden sebanyak 34 orang guru. Area yang menjadi indikator kompetensi guru kelas dalam pelaksanaan pembelajaran bernuansa bimbingan di SDLB yaitu menguasai identifikasi dan asesmen peserta didik, menguasai teori belajar \& prinsip-prinsip pembelajaran yang mendidik, dan mengembangkan perangkat pembelajaran yang sesuai dengan prinsip-prinsip pembelajaran bernuansa bimbingan. Hasil penelitian menunjukkan bahwa dalam penguasaan identifikasi dan penilaian siswa sebagian besar pada kategori kurang kompeten, sebagian kecil kompeten dan sisanya kurang kompeten. Pada kemampuan penguasaan teori pembelajaran dan prinsip-prinsip pembelajaran yang mendidik menunjukkan bahwa sebagian besar berada pada kategori kompeten dan sisanya pada kategori kurang dan tidak kompeten, sedangkan kemampuan mengembangkan perangkat pembelajaran mengikuti bimbingan bernuansa pembelajaran adalah sebagian besar pada kategori istirahat kompeten sangat kompeten, inkompeten dan kurang kompeten. Berdasarkan data yang diperoleh dalam hasil penelitian menunjukkan bahwa kompetensi guru kelas SD sangat luar biasa dalam menyelenggarakan pembelajaran bernuansa bimbingan dan menunjukkan kompetensi yang baik sehingga masih memerlukan bantuan pengembangan dengan menggunakan berbagai teknik, metode, strategi, dan pendekatan yang tepat.
\end{abstract}

Kata Kunci: Kompetensi Guru Kelas di SDLB, Pembelajaran Bernuansa Bimbingan. 


\section{INTRODUCTION}

Getting quality educational services is the right of every child, both normal children and special needs. Students with Special Needs or Children with Disabilities, including those at the Extraordinary Primary School, have the same basic needs and rights to grow and develop as other children according to their potential. Even Armstrong (2006) asserts that all children are talented. Each child is born into a world with unique potential, which, if properly nurtured, can contribute to a better world. The biggest challenge is to get rid of large stones that block their paths in finding, developing, and celebrating their gifts. The perspective of the Al-Quran, it is even emphasized that humans were created in the best and good form (QS.At-Tiin: 4-6). All potential learners with special needs should be developed. To develop the potential of Students with Special Needs holistically, learning services through instructional approaches or learning in the classroom is not enough, but requires learning in the nuances of guidance. The paradigm that occurs in Special Education and Special Services Education, which was originally based on a fatalistic philosophy, becomes a philosophical perspective. This has an impact on the existence of children with special needs having a good future perspective. Thus, if children with special needs obtain quality and meaningful educational services by taking into account all the potentials and obstacles they have, the child's potential will develop optimally. Guidance education is the main thing in optimizing children's potential. The school environment is a place for Students with Special Needs to learn about many things. Counseling Guidance as an integral part of education should be able to help students with Special Needs in understanding themselves and their environment if Special School teachers have competence in carrying out Guidance and Counseling. Previous research by Hernawati (2000), Soendari T, (2002, 2011), Liando (2003), and Mahmud (2004) concluded that the implementation of Counseling Guidance services for children with special needs in schools, including those in Extraordinary Primary Schools, was not optimal. Among the contributing factors is due to the absence of special counselors for children with special needs, the unavailability of special programs, the absence of optimal cooperation between the school and parents of Students with Special Needs in carrying out guidance and counseling services in schools. Furthermore, Sunardi (2005) emphasized that the activities of guidance and counseling services in Extraordinary Schools and also Extraordinary Primary Schools were not optimal due to the lack of competent human resources so that the guidance and counseling service activities became undirected and did not have a clear workflow because it was immediately carried out by classroom teachers who do not have a background in scientific guidance and counseling. Guidance and counseling services 
should be done professionally to produce optimal services. They can help all students including those in Extraordinary Primary Schools to create an atmosphere of learning that is fair and nondiscriminatory (Granello, F. Paul \& Hanna, J. Fred (2003), Spangenberg, J. Judora (2003) In this context the presence of qualified and competent Extraordinary Primary School teachers is a necessity and a demand because competent teachers play a very significant role in creating a meaningful and enjoyable learning atmosphere. Meaningful learning can be realized if professional educators do it. Republic of Indonesia Government Regulation number 19 of 2005 concerning National Education Standards in Chapter VI article 28 paragraph 1, states that "Educators must have academic qualifications and competencies as agents of learning, be healthy physically and spiritually, and have the ability to realize national education goals". The competencies in question are competencies that have been set by the government, including pedagogical competencies, personal competencies, social competencies, and professional competencies. The quality of classroom teachers has so far remained an important and crucial issue. This also happened to teachers who worked in an Extraordinary Elementary School. Extraordinary Elementary School Teachers as class teachers have an obligation to carry out Guidance and Counseling, as mentioned in the Minister of Education Regulation Number 35 of 2010 concerning Technical Implementation Guidelines for Teacher Functional Position and Credit Score. However, in general, Special School teachers do not have an educational background in Counseling Guidance. When completing education at the S1 / Bachelor level in Special Education in Higher Education, the teachers only get 2 (two) SKS courses for Introduction to Counseling Guidance. Thus Extraordinary School teachers solve problems that occur in class or develop the potential of students in their own ways. There is no standard operating procedure that must be done by the teacher when going to implement Guidance and Counseling. Elsewhere, Law No. 14 of 2005 concerning teachers and lecturers mandates that teachers are professional educators with the main task of educating, teaching, guiding, directing, training, evaluating, and evaluating students in early childhood education through formal education, basic education, and middle education. Based on the problems developed above, this article focuses on the study of the Competence of Class Teachers in the Implementation of Guided Learning in Extraordinary Primary Schools, Analysis of the Profile of Teachers' Ability in Identifying and Assessing Learners, Mastering Learning Theory and Principles of Educating Learning, and Developing Learning Tools. 


\section{METHODS}

This research was conducted through a quantitative approach with a descriptive method that is to describe the behavioral tendencies of a population quantitatively by examining the population sample (Creswell, W. J (2009). In this study, the description is the competency of elementary school teachers in conducting nuanced learning guidance that includes the competence of identifying and assessing students, mastering learning theories and principles of learning that educate, and developing learning tools. The subjects in this study were 34 teachers in Bandung District who served in Extraordinary Schools both Extraordinary Elementary Schools, Schools Extraordinary Junior High School and Extraordinary Senior High School by using a thematic approach in learning caused by teaching in the lower class (class IIV for the types of extraordinary impairment of the Blind (A), Deaf (B) and Deaf (D) or due to obstacles in this intellectual education unit for specific types of mental retardation (C) and autism with certain constraints. The instrument needed in data collection is a questionnaire that refers to Permendiknas Number 32 of 2008 concerning Academic Qualification Standards and Special Education Teacher Competencies.

\section{RESULTS AND DISCUSSION}

\section{Result}

The results of the study are related to the competence of elementary school teachers in the form of (1) the ability of teachers to identify and assess students, (2) master the learning theory and principles of educating learning, and (3) develop the learning tools described as follows.

\section{Special School Teacher Competency Profile in Mastering Student Identification and Assessment.}

Table 1. Competency of Identification and Assessment

\begin{tabular}{|c|c|c|c|c|c|c|c|c|c|}
\hline \multirow[t]{2}{*}{ NO } & \multirow[t]{2}{*}{ STATEMENT } & \multicolumn{2}{|c|}{ I } & \multicolumn{2}{|c|}{ NC } & \multicolumn{2}{|c|}{ C } & \multicolumn{2}{|c|}{$\mathrm{VC}$} \\
\hline & & $\mathbf{F}$ & $\%$ & $\mathbf{F}$ & $\%$ & $\mathbf{F}$ & $\%$ & $\mathbf{F}$ & $\%$ \\
\hline 1. & $\begin{array}{l}\text { Develop informal identification and assessment } \\
\text { instruments for learning }\end{array}$ & 6 & 17.7 & 8 & 23.6 & 20 & 59 & 0 & 0 \\
\hline 2. & $\begin{array}{l}\text { Conduct informal identification and assessment for } \\
\text { learning. }\end{array}$ & 4 & 11.8 & 4 & 11.8 & 24 & 70.8 & 2 & 5.9 \\
\hline 3. & $\begin{array}{l}\text { Prepare reports on the results of identification and informal } \\
\text { assessment for learning. }\end{array}$ & 6 & 17.7 & 8 & 23.6 & 18 & 53.1 & 2 & 5.9 \\
\hline & TOTAL & 16 & 15.7 & 20 & 19.7 & 62 & 60.9 & 4 & 3.9 \\
\hline
\end{tabular}

Based on table 1 above, obtained information about the competence of elementary school teachers in mastering the identification and assessment of learners in a variety ranging from 
(TK) Not Competent to (SK) Very Competent. Based on the above table, it was revealed that the indicators mastered the identification and assessment of students with the three statements examined, as follows: (1) Developing identification and assessment instruments for learning, the results obtained were $17.7 \%$ of teachers in the Incompetent category, $23.6 \%$ of teachers were in the category Less Competent, $59.0 \%$ are in the Competent category, and $0 \%$ are in the Very Competent category. (2) Identifying and evaluating informally for learning, the results obtained are $11.8 \%$ of teachers in the category of Incompetent, $11.8 \%$ of teachers are in the category of Less Competent, $70.8 \%$ are in the Competent category, and $5.9 \%$ are in the Highly Competent category. (3) Prepare reports on the results of identification and informal assessment for learning, the results obtained are $17.7 \%$ of teachers in the category of Incompetent, $23.6 \%$ of teachers are in the category of Competent, $53.1 \%$ are in the category of competence and $59 \%$ are in the category of Very Competent.

\section{Special School Teacher Competency Profile in mastering learning theory and principles of learning that educate}

Table 2. Competency of Mastering Theory and Principles of Educating Learning

\begin{tabular}{|c|c|c|c|c|c|c|c|c|c|}
\hline \multirow[t]{2}{*}{ NO } & \multirow[t]{2}{*}{ STATEMENT } & \multicolumn{2}{|c|}{ I } & \multicolumn{2}{|c|}{ NC } & \multicolumn{2}{|c|}{$\mathbf{C}$} & \multicolumn{2}{|c|}{ VC } \\
\hline & & $\mathbf{F}$ & $\%$ & $\mathbf{F}$ & $\%$ & $\mathbf{F}$ & $\%$ & $\mathbf{F}$ & $\%$ \\
\hline 1. & $\begin{array}{l}\text { Planning learning activities that are interrelated with } \\
\text { each other, taking into account the learning objectives } \\
\text { and learning process of students }\end{array}$ & 2 & 5.9 & 4 & 11.8 & 24 & 70.8 & 4 & 11.8 \\
\hline 2. & $\begin{array}{l}\text { They are providing opportunities for students to master } \\
\text { learning materials according to their potential, abilities, } \\
\text { obstacles, and learning needs through the arrangement } \\
\text { of various learning processes and activities. }\end{array}$ & 2 & 5.9 & 12 & 35.4 & 18 & 53.1 & 2 & 5.9 \\
\hline 3. & $\begin{array}{l}\text { Ensuring the level of students' understanding of certain } \\
\text { learning materials and adjusting subsequent learning } \\
\text { activities based on that level of understanding. }\end{array}$ & 0 & 0 & 12 & 35.4 & 20 & 59 & 2 & 5.9 \\
\hline 4. & $\begin{array}{l}\text { Explain the reasons for carrying out the } \\
\text { activities/activities carried out, both appropriate and } \\
\text { different from the learning plan, related to the success } \\
\text { of learning. }\end{array}$ & 2 & 5.9 & 12 & 35.4 & 16 & 47.2 & 4 & 11.8 \\
\hline 5. & $\begin{array}{l}\text { We are using various techniques to motivate student } \\
\text { learning. }\end{array}$ & 0 & 0 & 10 & 29.5 & 18 & 53.1 & 6 & 17.7 \\
\hline 6. & $\begin{array}{l}\text { Pay attention to the responses of students who have } \\
\text { obstacles in understanding the learning material being } \\
\text { taught and use them to improve learning designs. }\end{array}$ & 0 & 0 & 12 & 35.4 & 20 & 59 & 2 & 5.9 \\
\hline & TOTAL & 6 & 2.95 & 62 & 30.5 & 116 & 57 & 20 & 9.8 \\
\hline
\end{tabular}

Based on table 2 above, obtained information about the competence of special school teachers in mastering the theories and principles of learning that educate in a variety ranging from (TK) Not Competent to (SK) Very Competent. Based on the table above it is revealed that the 
indicators master the theory and principles of learning that educate with the six statements examined, as follows: (1) planning learning activities that are interrelated with each other by paying attention to the learning objectives and learning processes of students, the results obtained $5.9 \%$ of teachers are in the category of incompetence, $11.8 \%$ of teachers are in the category of less competent, $70.8 \%$ are in the category of competence and $11.8 \%$ are in the category of highly competent. (2) allowing students to master learning materials according to their potential, abilities, obstacles and learning needs through varied learning process settings and activities, the results obtained $5.9 \%$ of teachers are in the category of Incompetent, $35.4 \%$ of teachers are in the category of Less Competent, $53.1 \%$ are in the Competent category, and $5.9 \%$ are in the Very Competent category. (3) ensure the level of students' understanding of certain learning materials and adjust the subsequent learning activities based on the level of understanding, the results obtained $0 \%$ of teachers are in the category of Not Competent, $35.4 \%$ of teachers are in the category of Less Competent, $59.0 \%$ are in the category of Competent and $5.9 \%$ is in the Very Competent category. (4) explains the reasons for carrying out the activities/activities that are carried out, both those that are appropriate and different from the learning plan, related to the success of learning, the results are obtained $5.9 \%$ of teachers are in the category of Incompetent, $35.4 \%$ of teachers are in the category of Less Competent, $47.2 \%$ are in Competent category and $11.8 \%$ are in the Very Competent category. (5) Using various techniques to motivate learners' learning, the results obtained $0 \%$ of teachers are in the category of Not Competent, $29.5 \%$ of teachers are in the category of Not Competent, $53.1 \%$ are in the Competent category, and $17.7 \%$ are in the category of Very Competent. (6) pay attention to the responses of students who have obstacles in understanding the learning material being taught and use it to improve learning design. The results obtained $0 \%$ of teachers are in the category of Incompetent, $35.4 \%$ of teachers are in the category of Less Competent, $59.0 \%$ are in the category of Competent and $5.9 \%$ are in the category of Very Competent.

\section{Extraordinary Primary School Teacher Competency Profile in developing learning tools}

Table 3. Competencies of Developing Learning Devices

\begin{tabular}{|c|c|c|c|c|c|c|c|c|c|}
\hline \multirow[t]{2}{*}{ NO } & \multirow[t]{2}{*}{ STATEMENT } & \multicolumn{2}{|c|}{ I } & \multicolumn{2}{|c|}{ NC } & \multicolumn{2}{|c|}{$\mathbf{C}$} & \multicolumn{2}{|c|}{ VC } \\
\hline & & $\mathbf{F}$ & $\%$ & $\mathbf{F}$ & $\%$ & $\mathbf{F}$ & $\%$ & $\mathbf{F}$ & $\%$ \\
\hline 1. & $\begin{array}{l}\text { Adjusting the curriculum based on the results of } \\
\text { identification and assessment for the development of } \\
\text { lesson plans or PPI }\end{array}$ & 2 & 5.9 & 10 & 29.5 & 20 & 59 & 2 & 5.9 \\
\hline 2. & $\begin{array}{l}\text { Choosing learning materials that are following the } \\
\text { learning objectives, appropriate and up-to-date, }\end{array}$ & 2 & 5.9 & 10 & 29.5 & 20 & 59 & 0 & 0 \\
\hline
\end{tabular}


abilities, can be implemented in the class, and accordance with the context of students' daily life

3. Develop learning outcome assessment instruments by paying attention to indicators, materials, and abilities of students.

TOTAL

Note: I = Incompetent; NC= Not Competent; $C=$ Competent; $V \mathrm{CC}=$ Very Competent

Based on table 3 above, information about SLB teacher competencies in developing learning tools varies from (TK) Incompetent to (SK) Very Competent. Based on the table above, it was revealed that the indicators for developing learning tools with the three statements examined were as follows: (1) adjusting the curriculum based on the results of identification and assessment for the development of RPP or PPI, the results obtained 5.9\% of teachers were in the category of Not Competent, $29.5 \%$ of teachers were in the Less Competent category, $59.0 \%$ were in the Competent category and 5.9\% were in the Very Competent category. (2) choosing learning materials that are by the learning objectives, appropriate and up-to-date, according to the needs and level of learning ability of students, can be implemented in the classroom, and under the context of students' daily lives, obtained 5.9\% of teachers are at Incompetent category, $29.5 \%$ of teachers are in the Less Competent category, $59.0 \%$ are in the Competent category, and $5.9 \%$ are in the Very Competent category. (3) compile an instrument for evaluating learning outcomes by taking into account the indicators, materials, and abilities of students. the results obtained $0 \%$ of teachers are in the category of Not Competent, $29.5 \%$ of teachers are in the category of Not Competent, $64.9 \%$ are in the Competent category, and 5.9\% are in the category of Very Competent.

\section{Discussion}

The results showed that the ability of special elementary school teachers to conduct assessments was generally in the category of less competent towards competent. This shows that SDLB teachers still need help to develop their ability to conduct assessments. The assessment is critical to achieve quality education for Students with Special Needs, ranging from instrument development, implementation of reporting. The principle of assessment for children is the process of understanding the level of development and growth of the child's ability to continuously by collecting data through observation, recording, recording, of the behavior displayed in Rasyid, 2012 (in Zainal Alimin 2007). Every child must experience growth and development in his life series. Assessment is the process of measuring something compared to something that has been standardized. As mentioned by Godwin \& Godwin (Wortham, 2005) drawing an assessment or measurement is "the process of determining, 
through observation or testing, individual traits or behavior, a program's characteristics, or the properties of some other entity, and then assigning a number, rating, or score to that determination. "According to James E Johnson (in Uyu Wahyudin \& Mubiar Agustin, 2011) assessment or assessment is' in general, evaluation is the process of selecting, gathering, and interpreting information to make personal decisions or two from judgment about the worth of product or program or about the value of an approach to solve a problem or accomplish an objective '. Assessment or assessment is the process of selecting, collecting, and interpreting information to make decisions or to make judgments about the weaknesses of a product or program, or about the extent to which the success of the approach that has been done can solve the problem so that it can perfect a goal or goal. As for competence in mastering learning theory and the principles of learning that educate, it appears that this competency tends to be in the category of competent towards very competent. Even though it looks positive it does not mean that SDLB teachers do not need self-development in this competency. Mastering learning theory and teaching principles of learning are essential. With this ability, educators will be able to carry out learning by the level of development of students. One example of student development is intellectual development. Teachers who master the theory of intellectual development will be able to adjust learning that starts from the sensorimotoric, preoperational, concrete operational, and formal operational stages, as revealed in Piaget's learning theory. Mastering learning theory will have an impact on various things that teachers do from approaches, strategies, methods, facilities, and facilities used and learning techniques that lead to the quality of GDPK learning outcomes. The following are some of the results of research related to learning (Situmeang and Hamid (2015). Besides, mastery of SDLB teachers on learning theory will help them to create an atmosphere of learning in more pleasant and meaningful interactions (Agustin, M 2017, Agustin, M et al. 2020). Associated with the competence of developing learning tools the results of research show quite diverse achievements even though in general in the category of competent leads to very competent Developing learning tools is necessary for a teacher starting from planning, implementation to evaluation, learning tools will greatly help teachers in conveying the process seeking knowledge to students Borich (2007) states "Planning is the systematic process of deciding what and how your students should learn." Planning is a systematic process of deciding what and how students should learn so that quality and pro learning ductivity.

\section{CONCLUSIONS}


The results showed that the Teacher's Ability in Identifying and Assessing Students, Mastering Learning Theory and Principles of Learning that Educate, and Develop Learning Tools tend to be in the category of competent towards very competent. This shows that Extraordinary Elementary School teachers still need assistance either in the form of supervision or education and training activities to develop the three competencies so that practical and accommodative guidance learning activities can be achieved for the needs of every child in school. On the other hand, Extraordinary Elementary School Teachers also need to be given skills that can make them more confident in doing learning activities with children in the class. Extraordinary Elementary School Teachers also need to be equipped with maximum insight and knowledge and skills to develop their abilities in their experience-based research activities in conducting classroom nuanced learning activities.

\section{ACKNOWLEDGMENTS}

Thanks to the Indonesian Education University and the West Java Provincial Education Office for providing support so that this research is carried out well.

\section{REFERENCES}

Agustin, M (2017) Mengajar yang Menyenangkan dan Bermakna Bagi Anak. Edena Ciptawira. Bandung.

Agustin, M et al. (2020)" Burnout Profile of Elementary School Teacher Education." Students (ESTES): Factors and Implication of Guidance and Counseling Service". Journal of Elementary Education Volume 4 Number 1. February 2020. Page 38-47.

Alimin, Z. (2007). Modul Hambatan Belajar dan Perkembangan 1, Bandung: Pascasarjana Prodi Pendidikan Khusus UPI.

Armstrong, T (2006) The Best Schools. Mendidik Siswa Menjadi Insan Cendekia Seutuhnya. Penerbit Kaifa. Bandung.

Borich, G.D., 2007. Effective Teaching Methods Research-Based Practice Sixth Edition New Jersey: Pearson Merrill Prentice Hall.

Creswell, W.J (2009). Research Design Qualitative, Quantitative, and Mixed Methods Approaches. Third Edition. SAGE publications. Thousand Oaks, California.

Hernawati, T. (2000). Program Layanan Dasar Bimbingan dalam Mengembangkan Perilaku Sosial Sswa Tunarungu di SLB. Tesis pada PPs UPI Bandung: tidak diterbitkan.

Granello, F. Paul \& Hanna, J. Fred (2003) "Inceacerated and court-involved Adolescents: Counseling an At-Risk Population." JCD Journal of Counseling \& Development Volume 81, Number 1 Winter 2008.

Liando, Y. (2003). Kesesuain antar Pelaksanaan Bimbingan oleh Guru dengan Harapan Orang Tua. Tesis pada PPs IKIP Bandung: Tidak diterbitkan. 
Mahmud, M. (2004). Layanan Bimbingan bagi Anak Tunagrahita di SD. Jurnal Ilmu Pendidikan Pedagogia, Vol 2 No 1 Tahun 2004. ISSN: 1693-5276. Hal. 33-45.

Peraturan Menteri Pendidikan Nasional nomor 16 tahun 2007 tentang standard kualifikasi akademik dan kompetensi guru.

Peraturan Menteri Pendidikan Nasional Republik Indonesia Nomor 32 Tahun 2008 Tentang Standar Kualifikasi Akademik Dan Kompetensi Guru Pendidikan Khusus.

Peraturan Menteri Negara Pemberdayaan Aparatur Negara dan Reformasi Birokrasi (Permenagpan RB) nomor 16 tahun 2009 tentang Jabatan Fungsional Guru dan Angka Kreditnya.

Permendiknas nomor 35 tahun 2010 tentang Juknis Pelaksanaan Jabatan Fungsional Guru dan Angka Kreditnya.

Spangenberg, J. Judora (2003) "The Cross-Cultural Relevance of Person-Centered Counseling in Postapartheid South Africa."'. JCD Journal of Counseling \& Development Volume 81, Number 1 Winter 2008.

Soendari, T. (2002), Pemahaman dan Penerapan Konsep-Konsep Dasar Bimbingan dalam Proses Belajar Mengajar di SLB-C. Tesis pada PPs UPI: Tidak diterbitkan.

Soendari, T. (2011). Model Bimbingan dan Konseling Kolaboratif Dalam Pengembangan Perilaku Adaptif Anank Tunagrahita Ringan di Sekoah Dasar. Disertasi pada PPs UPI: Tidak ditebitkan.

Sunardi (2005). Pedoman Pelaksanaan Program Layanan Bimbingan dan Konseling di Sekolah Luar Biasa. Bandung: Universitas Pendidikan Indonesia.

Wortham, C.S (2005) Assessment in Early Childhood Education. Fourth Edition. Pearson Prentice Hall. United State.

Wahyudin, U \& Agustin, M. ( 2011). Penilaian Perkembangan Anak Usia Dini. Bandung: Refika Aditama. 